\title{
内部架構構成からみた中期ビザンツ文化圈内接十字型教会堂建築の成り立ち THE DEVELOPMENT OF THE CROSS-IN-SQUARE CHURCH IN THE MIDDLE BYZANTINE
PERIOD IN TERMS OF ITS ARCHITECTURAL CONFIGURATION
}

\author{
樋口 諒*, 那須 聖**
}

Ryo HIGUCHI and Satoshi NASU

\begin{abstract}
The cross-in-square was one of the most common church forms in the middle Byzantine period (9th-12th centuries $\mathrm{CE}$ ). This paper looks at how the architectural configuration of the cross-in-square developed, focusing on the threedimensional characteristics of all churches within Byzantine territories, unlike previous studies. These churches are classified according to their floor plan; horizontal shape and construction methods of supports; the arrangement of arches; and the support and arch connection methods. Two architectural groups emerge: the centralised church-like configuration, in which the arches are placed on the supports, and the two-direction configuration, where the arches penetrate inner walls.
\end{abstract}

Keywords: Byzantine Architecture, Christian Architecture, Architectural Configuration, Cross-in-Square Church ビザンツ建築，キリスト教建築，架構構成，内接十字型教会堂

\section{1. はじめに}

395 年に東西に分裂したローマ帝国のうち東方の帝国、即ちビザン ツ帝国は、その領土の拡大と縮小を繰り返しつつも、1453年にその 首都コンスタンティノープルが陥落するまで 1000 年以上に亘り、地 中海の東沿岸部に存在した。この間、ビザンツ帝国において信奉さ れていた東方正教会の教義は、その版図外へも波及し、9世紀以降 にはブルガリアやロシアなどの周辺諸国も東方正教会を信仰するよ うになった ${ }^{1)}$ 。従って、恒久的にビザンツ帝国であった地域、および 一時的にビザンツ帝国の版図となりかつビザンツ帝国同様に東方正 教会の教義を信奉していた地域について、一つのキリスト教文化を 共有した「ビザンツ文化圈」と措定可能である(Fig. 1)。以降本稿では、 当該文化圈に創建された教会堂をビザンツ教会堂建築と呼称する。

1000 年以上に亘って存続したビザンツ教会堂建築については、 7〜8世紀の建築活動の一時的な衰退期を契機として、古代ローマ建 築の延長と見做すことのできる 7 世紀までの初期ビザンツ教会堂建 築から脱し、ビザンツ教会堂建築に固有の特質を有するようになっ たことが指摘されている ${ }^{2)}$ 。こ建築衰退期以降、8世紀末に出現し たとされる内接十字型は ${ }^{3)} 、$ 中期以降のビザンツ教会堂建築における、 最も一般的かつ聖堂から礼拝堂に至るまで多様な用途の教会堂に使 用される建築形式の一つとして、ビザンツ文化圏の広範な地域でみ られている点で特に注目に值する。当該建築形式は、既往研究を通

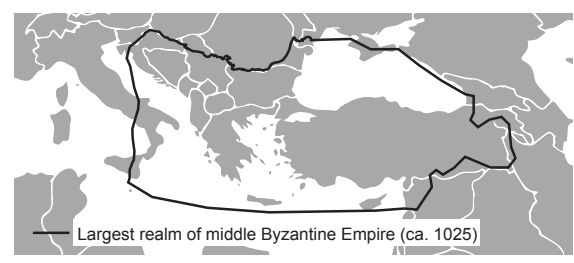

Fig. 1 Largest extent of the middle Byzantine Empire

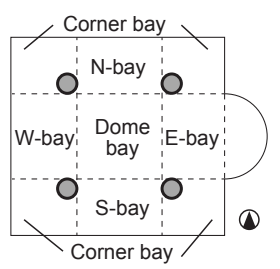

Fig. 2 Names of specific bays
じて大まかな合意こそ形成されているものの、明確な定義は存在し ておらず、例えばクラウトハイマーは、矩形平面の内部に 4本の円 柱を配置することによって生じる9つのベイから構成され、その中 央のベイにドームを冠し、その東西南北のベイにバレルヴォールト が架かり、四隅のベイにドームないしクロスヴオールトを架けたも のとしている ${ }^{4)}$ 。本稿では上記の区分に倣い、中央のドームが架かっ たベイをドームベイ (Dome bay)、その東西南北に隣接するべイをそ れぞれ東西南北ベイ ( 北ベイ :N-bay、南ベイ :S-bay、東ベイ:E-bay、 西ベイ:W-bay、東西南北ベイ:NSEW-bay)、残りのベイをコーナー ベイ (Corner bay) とし、これら 9 つのベイからなる部分を 9 ベイ部 $(9$ bays part) と呼称する (Fig. 2)。

ビザンツ教会堂建築史における、内接十字型の位置づけをみると、 7〜8世紀の遺構がほとんど現存しないこともあり、その成り立ち については未だ不明な部分が多い。内接十字型をビザンツ教会堂建

本稿の内容の一部は, 樋口諒, 藤田康仁, 守田正志, 篠野志郎「中期ビザンツ帝国の内接十字型教会堂建築における内部架構形式」,(『2014 年度(関西)学術講演梗概集』, 日 本建築学会,F-2 分冊, 803-804,2014.9) 及び, 樋口諒, 藤田康仁, 那須聖, 篠野志郎「中期ビザンツ文化圈に扮ける内接十字型教会堂建築にみるドームベイ隅部の柱の形式とそ の地域性」,(『2015 年度日本建築学会北海道支部研究報告集』,日本建築学会,329-334,2015.6)にて発表している。

東京工業大学大学院総合理工学研究科人間環境システム専攻 $\quad$ Doctoral Course, Tokyo Institute of Technology, M. Eng. 博士後期課程 · 修士 (工学)

***東京工業大学環境・社会理工学院建築学系 准教授・博士 (工学)

Assoc. Prof., Tokyo Institute of Technology, Dr. Eng. 
Table 1 Architectural characteristics of cross-in-square churches in previous studies

\begin{tabular}{|c|c|c|c|c|c|c|c|c|c|c|c|c|c|c|c|}
\hline \multirow{3}{*}{ Author } & \multirow{2}{*}{\multicolumn{3}{|c|}{$\begin{array}{c}\text { Number of bays } \\
\text { in main part }\end{array}$}} & \multicolumn{7}{|c|}{ Shape of ceiling } & \multicolumn{5}{|c|}{ Horizontal section of supports under the dome } \\
\hline & & & & \multirow{2}{*}{\begin{tabular}{|c|} 
Centre bay \\
Dome
\end{tabular}} & \multicolumn{2}{|c|}{ NSEW-bay } & \multicolumn{4}{|c|}{ Corner bay } & \multirow{2}{*}{ Circle } & \multirow{2}{*}{ Quadrangle } & \multirow{2}{*}{ Cir. + Quad. } & \multirow{2}{*}{ L-shape } & \multirow{2}{*}{ T-shape } \\
\hline & 12 & 9 & 15 & & Barrel vault & Cross vault & Dome & Domical vault & Cross vault & Barrel vault & & & & & \\
\hline J. Strzygowski & $\mathrm{O}$ & $\mathrm{O}$ & - & $\mathrm{O}$ & $\mathrm{O}$ & - & - & - & $\mathrm{O}$ & $\mathrm{OO}$ & (O & $\mathrm{O}$ & - & 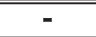 & - \\
\hline A. Orlandos & $\mathrm{O}$ & $\mathrm{O}$ & $\mathrm{O}$ & 0 & $\mathrm{O}$ & - & $\mathrm{O}$ & $\mathrm{O}$ & $\mathrm{O}$ & $\mathrm{O}$ & $\mathrm{O}$ & $\mathrm{O}$ & $\mathrm{O}$ & - & $\mathrm{O}$ \\
\hline R. Krautheimer & $\mathrm{O}$ & $\mathrm{O}$ & - & 0 & 0 & 0 & 0 & 0 & 0 & 0 & 0 & $\Delta$ & 0 & $\Delta$ & - \\
\hline C. Mango & 0 & 0 & - & 0 & 0 & 0 & 0 & 0 & 0 & 0 & 0 & 0 & 0 & 0 & - \\
\hline S. Ćurčić & 0 & 0 & 0 & 0 & 0 & 0 & 0 & 0 & 0 & 0 & 0 & 0 & 0 & 0 & 0 \\
\hline
\end{tabular}

Note on Table 1: $\bigcirc$ : including, $\triangle$ : refering as cross-in-square as well as other name, -: unknown because the author does not refer,

Cir. + Quad.: western supports are circle and eastern supports are quadrangle

築史の中で位置づけようとした試みの例として、内接十字型という 概念を初めて呈示したストゥルツゴフスキーは、当該建築形式を十 字平面の建築に四つのベイが附設したものと見做し5)、また、現在ま で踏襲される、内接十字型をその平面的特徵によってさらにいくつ かへ分類する手法を編み出したミレーは、分類した内接十字型のう ちの一つの起源をストゥルツゴフスキー同様十字形平面の建築とし、 別のものの起源をドーム附設バシリカとしている ${ }^{6}$ 。このような研究 は特に 20 世紀前半に多くみられ、既往研究についてランゲは、矩形 外形の教会堂から発展したとするもの、十字形の教会堂から発展し たとするもの、およびローマ・イラン建築における類似した建築形 式を模したものとするものの3 種類に大別している7”。こ字形外 形と矩形外形のいずれから内接十字型が生じたかという議論は、換 言すれば、内接十字型をドームを冠した十字平面の教会堂にさらに ベイを附属させたものとして捉えるか、ドームを有する矩形外形の 教会堂の内部の構成が变化したものとして捉えるかといえる。しか し、内接十字型がどのような先行建築から生じたのかについて結論 が出ているとは言えない。その理由として、多くの既往研究がビザ ンツ教会堂建築を西欧建築において一般的な分析方法である平面形 式に基づいて分類しており、ビザンツ建築そのものの独自性につい ては十分に検討して無い点をオスターフートは指摘している ${ }^{8)}$ 。

これらに対し近年の研究では、検討対象とする教会堂の数を絞っ た上での詳細な分析を行い、それらを一般的な内接十字型の中で位 置づける傾向がみられる ${ }^{9)}$ 。その一方で、この一般的とされる内接十 字型そのものは、十分な検討に基づいて導かれた概念ではなく、単 にビザンツ帝国の首都であったコンスタンティノープルの教会堂と の比較になってしまっている場合が多くみられる ${ }^{10)}$ 。しかし、コン スタンティノープルに先行して地方で内接十字型の教会堂が出現し ていた事実を鑑みれば同、内接十字型の系譜を考えるためには、ビ ザンツ文化圈全体を対象として具体的な変遷を追う必要がある。

従って本稿では、こうした既往研究が平面分析を中心としてきた 点、および分析対象が数量的にも地理的にも限られ、総体としての 内接十字型への理解がなおざりとされてきた点を批判的に捉え、内 接十字型の教会堂を平面的な特徴のみならず、立体的な形態とその 構法、即ち架構に着目して検討し、内接十字型の成り立ちについて 再考することを目的とする。既往研究は、内接十字型を十字形外形 ないし矩形外形のいずれかから派生したものと見做しており、これ は前者の場合、「ドームの架かった中央ベイおよびその東西南北に位 置し十字状にヴォールトが架かったベイの部分」（以下、十字部）に 「十字のベイの隅部に設けられるベイの部分」(以下、コーナーベイ部) が附設されたものとして捉え、後者の場合でも、十字部とコーナー
ベイ部とを異なる空間として捉えている。従って、本稿では二つの 異なる空間がどのように接続されているかに着目して分析を行う。 具体的には、十字部とコーナーベイ部の接続構面におけるアーチ開 口の高さの違いを両者の接合・分節の度合いを示すものとして捉え、 アーチを含む接続構面の形態的な特徴に着目して類型化を行うと共 に、架構の観点から類型同士の相互関係について検討する事により、 中期ビザンツ内接十字型教会堂の成り立ちについて考察を行う。検 討対象とする教会堂は、内接十字型の出現が認められる8世紀末以降、 第四回十字軍によってコンスタンティノープルが占拠される 1204 年 までに創建されたもののうち、分析をするに足る情報を得られたも のとした。1204年を検討対象年代の下限としたのは、コンスタンティ ノープルの十字軍による占拠以降、ビザンツ文化圈には多くの小国 が乱立し、政治的にも宗教的にも複雑なモザイクのような様相を呈

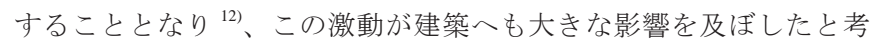
えられるためである ${ }^{13)}$

本論の構成の概略を示す。2 章では、ビザンツ教会堂建築における 内接十字型の概念が必ずしも確定していないことから、論考を進め るにあたって妥当性を持つ概念を規定し、その概念を元に検討対象 遺構を選定する。3章では、選定された遺構について、十字部とコー ナーベイ部との接続面における形態的な特徴に着目して類型化を行 い４章では抽出された各類型における形態と構法との関係性に注目 してそれぞれの特徴を明らかにし、架構的な特質から内接十字型の 成り立ちについて考察を行う。

\section{2. 内接十字型教会堂の分類規範}

内接十字型を分析するのに先立ち、まず既往研究において内接十

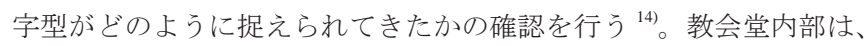
信徒のための空間であるナオスと聖職者のみが入ることのできる心゙ マに弁別され ${ }^{15)}$ 、両者の間には障壁が置かれる。本稿では、このよ うなナオスとベマによって構成される、典礼などの教会堂の基本的 な行為を行う部分について便宜的に主部（Main part）と呼称する。

これまでの本稿の用語に基き、既往研究における内接十字型とい う語の示す範囲を形態的特徴に基づいて Table 1 のように比較・対照 した ${ }^{16)}$ 。内接十字型の定義が著者によって異なることから、具体的 な対象となる教会堂に差異がみられるものの、いずれの場合におい ても、内接十字型とされる教会堂は、主部の中央のベイにドームが 架かる点、東西南北ベイに十字状にヴォールトを配置する点で共通 している。また、主部のベイ数や東西南北ベイおよびコーナーベイ の天井面架構、ドームベイの隅部に配置される柱（以下、隅部柱 : Supports）の断面形状については、著者ごとに内接十字型として直 


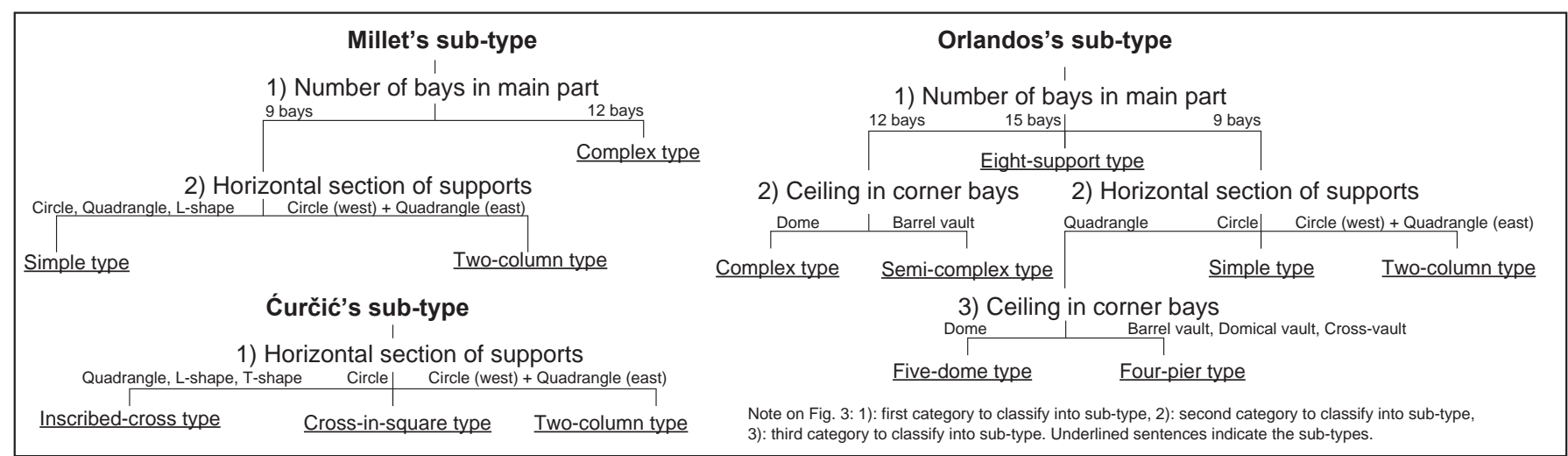

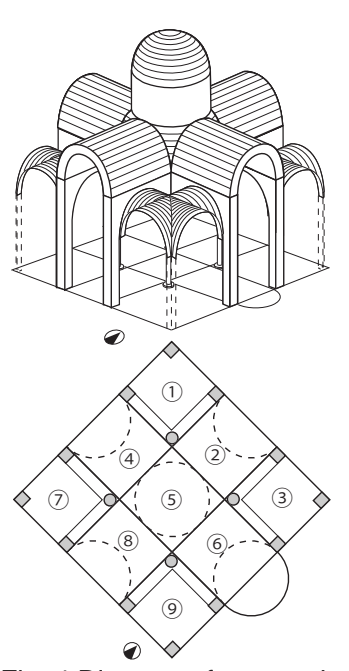

Fig. 4 Diagram of a cross-insquare church

Fig. 3 Cross-in-square sub-types featured in previous studies

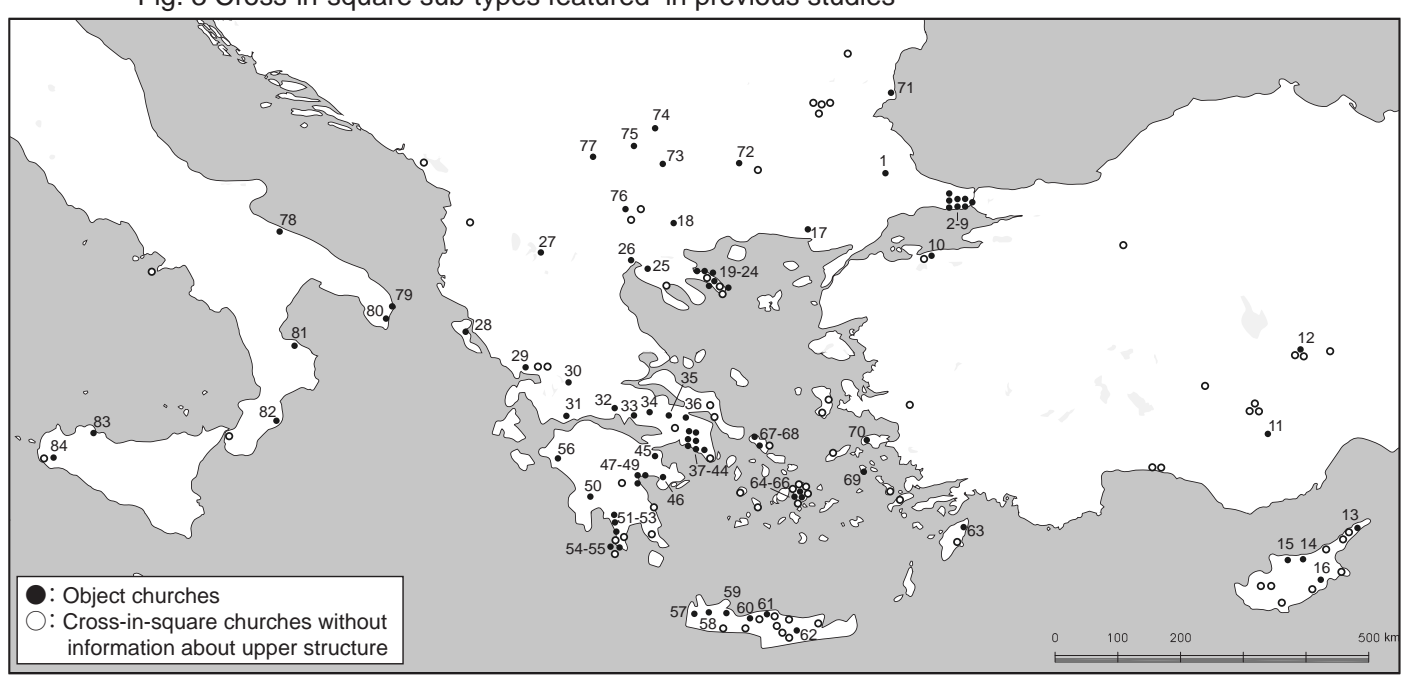

Fig. 5 Location of cross-in-square churches from the middle Byzantine period

接言及している範囲にばらつきもみられるものの、いずれの著者も 内接十字型と見做す条件として、主部のベイ数が 9 つないし 12 個 であること、東西南北ベイの天井面架構がバレルヴォールトである こと、コーナーベイの天井面架構がクロスヴォールトないしバレル ヴォールトであること、および隅部柱の断面形状が全て円形ないし 矩形であることをあげることができる。一方、主部が 15 ベイとなる 教会堂や東西南北ベイの上部にクロスヴォールトを架けている教会 堂、コーナーベイの天井面をドームないしペンデンティヴドームと している教会堂、隅部柱として異なる断面形状のものを組み合わせ たり、L字形や丁字形のものを用いる教会堂に関しては、著者によっ ては内接十字型であるか否かを明示していない。Table 1のように、 チュルチッチは最も広範な形態の教会堂を内接十字型としているの に対し、ストゥルツゴフスキーが対象としている形態の教会堂は他 の著者と比較しても限られる ${ }^{17)}$ 。またクラウトハイマーは、特定の 形態の教会堂に対して、内接十字型および別の語句を用いている ${ }^{18)}$

続いて、既往研究における建築形式の類型と内接十字型の用例之 の関係性をみてみると、ストゥルツゴフスキーおよびクラウトハイ マー、マンゴーは内接十字型を一つの建築形式としている。一方ミ レーおよびオーランドス、チュルチッチは内接十字型を Fig. 3のよう に、隅部柱の断面形状や主部のベイ数、ないしはコーナーベイの天 井面架構によって更に分類可能なもの、換言すれば複数の建築形式 よりなるものとしている。内接十字型を分類する際にそれぞれの基 準を見てみると、ミレーは主部のベイ数によって教会堂を弁別した
上で、隅部柱の断面形状によってさらに分類し、チュルチッチは隅 部柱の断面形状にのみ着目し、いずれも3つの形式に整理している。 オーランドスはミレーと同様に主部のベイ数によってまず教会堂を 分類した上で、隅部柱の断面形状およびコーナーベイの天井面の架 構によって分類し、計 7つの形式に整理している。特にオーランド スによる内接十字型の分類手法は以後多くの研究に踏襲されており、 近年のカロピシ - ヴェルティらの分類では、内接十字型を基本的には オーランドスの手法を踏襲して8つの形式に整理しつつ、主部に附 属するその他の構造物によって計 10 の形式を指摘している ${ }^{199}$ 。但し いずれの分類手法においても分類された類型相互の関係性について はほとんど検証されておらず、ミレーの提起した 9 ベイの教会堂を バルカン半島の形式とし、12ベイの教会堂をコンスタンティノープ ル周辺の形式とする考え方を殆ど無批判に踏襲している ${ }^{20)}$

このように、内接十字型の捉え方には既往研究ごとに違いがみら れ、また内接十字型をさらに分類する際には、隅部柱の断面形状や 主部のベイ数のように平面的な特徴に着目して分類が行われてきた。 以上を踏まえ、内接十字型の成り立ちを考察する上では、これまで 内接十字型として捉えられてきた教会堂を可能な限り多く対象とし た上で、立体的な特徴も含めて分析する必要がある。従って、既往 研究において対象となっていた教会堂を余すこと無く網羅し得る要 素に着目すると、内接十字型とは、ドームの架かった中央ベイの四 方のベイへ十字状にヴォールトを配置し、その十字の隅部にさらに ベイを設けることによって生じる 9 ベイからなる構成を有する教会 
Table 2 Categories of classification and typology by architectural configuration

\begin{tabular}{|c|c|c|c|c|c|c|c|c|c|c|c|}
\hline \multirow[b]{2}{*}{ ID } & \multirow[b]{2}{*}{ Name } & \multirow[b]{2}{*}{ ocation } & \multirow[b]{2}{*}{ n. } & \multirow[b]{2}{*}{ c } & & \multirow{2}{*}{\begin{tabular}{|c||}
$\mathrm{b}$ \\
$\begin{array}{c}\text { Connection } \\
\text { method }\end{array}$ \\
\end{tabular}} & \\
\hline & & & & & Arches & $\begin{array}{l}\text { Supports } \\
\text { pattern }\end{array}$ & Bays & \begin{tabular}{|c|} 
Positional \\
relation
\end{tabular} & Type & & \\
\hline & Trilye & Trilye & $9 \mathrm{C}$ & Turkey & Arch-(8) & Circle & 11 & Separate & A & Capital & 4. \\
\hline & Peristerai & Peristerai Mon. & $9 \mathrm{C}$ & Greece & Arch-(8) & Circle & 10 & Separate & & Capital & \\
\hline & Constantine Libos & Constantinople & $10 \mathrm{C}$ & urkey & Arch-(8) & Circle & 12 & Separate & & apital & \\
\hline & Myrelaion & Constantin & $10 \mathrm{C}$ & Turkey & Arch-(8) & ircle & 12 & Separate & & apital & \\
\hline & Vatopedi Katholikon & Mt. Athos & $10 \mathrm{C}$ & Greece & Arch-(8) & Circle & 12 & Separate & & Capital & 5. \\
\hline 22 & Ivirion Katholikon & Mt. Athos & $10 \mathrm{C}$ & Greece & Arch-(8) & Circle & 12 & Separate & & Capital & \\
\hline & Iviron H. lōannēs & Mt. Athos & $10 \mathrm{C}$ & Greece & Arch-(8) & Circle & 12 & Separate & & Capital & \\
\hline & Xenophontos & Mt. Athos & OC. & Greece & Arch-(8) & Circle & 12 & Separate & & Capital & \\
\hline & Panagia & H. Louka & $10 \mathrm{C}$ & Greece & Arch-(8) & Circle & 12 & Separate & & Capital & \\
\hline & Petrakē Katholikon & Athens & $10 \mathrm{C}$ & Greece & Arch-(8) & Circle & 12 & Separate & & & \\
\hline & Lavra & Mt. A & IC. & Greece & ch-(8) & Circle & 12 & \begin{tabular}{|l|} 
Separate \\
\end{tabular} & & ital & \\
\hline & Pantepoptes & Consta & 11C. & Turkey & Arch-(8) & Circle & 12 & \begin{tabular}{|l|} 
Separate \\
\end{tabular} & & apital & \\
\hline & Kilise $\mathrm{C}$ & Const & 1C. & Turkey & ch-(8) & rcle & 12 & Separate & & tal & \\
\hline & Panagia Chal & Thessale & $11 \mathrm{C}$. & Greece & Arch-(8) & Circle & 12 & Separate & & Capital & \\
\hline 39 & Kapnikar & Athens & $11 \mathrm{C}$. & Greece & ch-(8) & Circle & 12 & Separate & , & tal & \\
\hline & Pantokratc & Constanti & $12 \mathrm{C}$ & Turkey & Arch-(8) & Circle & 12 & Separate & 7 & apital & \\
\hline & Eleousa & Const: & $12 \mathrm{C}$ & Turkey & ch-(8) & ircle & 12 & Separate & & tal & 6. \\
\hline & Troull & Const & $12 \mathrm{C}$ & Turkey & Arch-(8) & C & 12 & Separate & & tal & \\
\hline 47 & Aria & Aria & $12 \mathrm{C}$ & Greece & Arch-(8) & Circle & 12 & \begin{tabular}{|l|} 
Separate \\
\end{tabular} & & Capital & \\
\hline & Sagn & Sagn & $12 \mathrm{C}$ & Greece & Arch-(8) & Circle & 12 & Separate & & zaplal & \\
\hline 48 & Chōnikas & Chōnikas & $12 \mathrm{C}$ & Greece & Arch-(8) & Circle & 12 & \begin{tabular}{|l|} 
Separate \\
\end{tabular} & & Capital & \\
\hline 49 & Merba & Merba & c. & Greece & ch-(8) & Circle & 12 & Sep & & tal & \\
\hline 82 & Stilo & Stilo & c. & & Arch-(8) & & 9 & in & & al & \\
\hline 21 & Vatope & Mt. Ath & ic. & Greece & Arch-(8) & rcle & s & djoin & & ital & \\
\hline 38 & H. A & Athens & C. & $\mathrm{G}$ & $h-(8)$ & & 9 & & & & \\
\hline 69 & Patmo & Patmo & ic. & Greece & ch-(8) & Circle & s & djoin & & apital & \\
\hline 70 & Potami & Samos & IC. & Greece & Arch-(8) & Circ & 9 & didoin & & Capital & \\
\hline 14 & Keryne & Kery & $2 \mathrm{C}$ & Cyprus & Arch-(8) & Circ & 9 & djoin & & apital & \\
\hline 18 & Elaiôn & Elaiōn & 2C. & Greece & Arch-(8) & Circ: & & djoin & & apital & \\
\hline 55 & Kitta & Kitta & c. & Greece & Arch-(8) & $\bar{c}$ & & Adjo & & tal & \\
\hline 58 & Alikiano & Crete & $12 \mathrm{C}$. & Greece & ch-(8) & Circ & 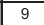 & Adjoin & & Capital & \\
\hline 60 & H. Dē & Crete & $12 \mathrm{C}$ & Greece & ch-(8) & Circle & & in & & tal & \\
\hline 75 & Rila & Rila & $12 \mathrm{C}$ & Greece & ch-(8) & Circle & 9 & Adjoin & & ital & \\
\hline 80 & Trani & & $12 \mathrm{C}$. & Ita & Arch-(8) & Circ & 9 & Adjoin & & apital & \\
\hline & Palern & & & & Arch-(8) & & 9 & . & & & \\
\hline 84 & Delia & Caste & $12 \mathrm{C}$. & tha & Arch-(8) & Circle & 9 & Adjoin & 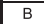 & apital & \\
\hline & Zem & Zeme & $12 \mathrm{C}$. & \begin{tabular}{|l|} 
Bulgaria \\
\end{tabular} & Arch-(8) & Qua & 9 & djoin & & & \\
\hline & Kala & Kalan & $2 \mathrm{C}$ & Turke & ch-(8) & Qua & & Adjoin & & Oonnice[S] & \\
\hline & Chall & Naxos & 11C. & Greece & Arch-(8) & Qua & 9 & Adjoin & & ornice & \\
\hline & & & 112 & & & & 9 & & & & \\
\hline 36 & Schēma & Schêm & $12 \mathrm{C}$ & Greece & Arch-(8) & Quad. & 9 & Adjoin & C & \begin{tabular}{|l|} 
Cornice $[R]$ \\
\end{tabular} & \\
\hline & & & & & & & & djoin & C & Step & \\
\hline
\end{tabular}

Note on Table 2: Cen.: Century; Arches: Arrangement of the arches and number of the highest arches (see Fig. 6); Supports pattern: Patterns of horizontal section of supports (Quad.: Quadrang see Fig. 7; grey colour means construction methods for supports and arches differ, half-grey colour means construction methods of western supports and arches are different, white cell means construction methods for supports and arches are the same); Bays: Number of bays in main part; Positional

relation: Positional relation of bema and dome bay (see Fig. 8); Connection methods: Connection methods for arches and supports (Capital: capitals are on the all supports, see Fig. 10-a; Direct: All

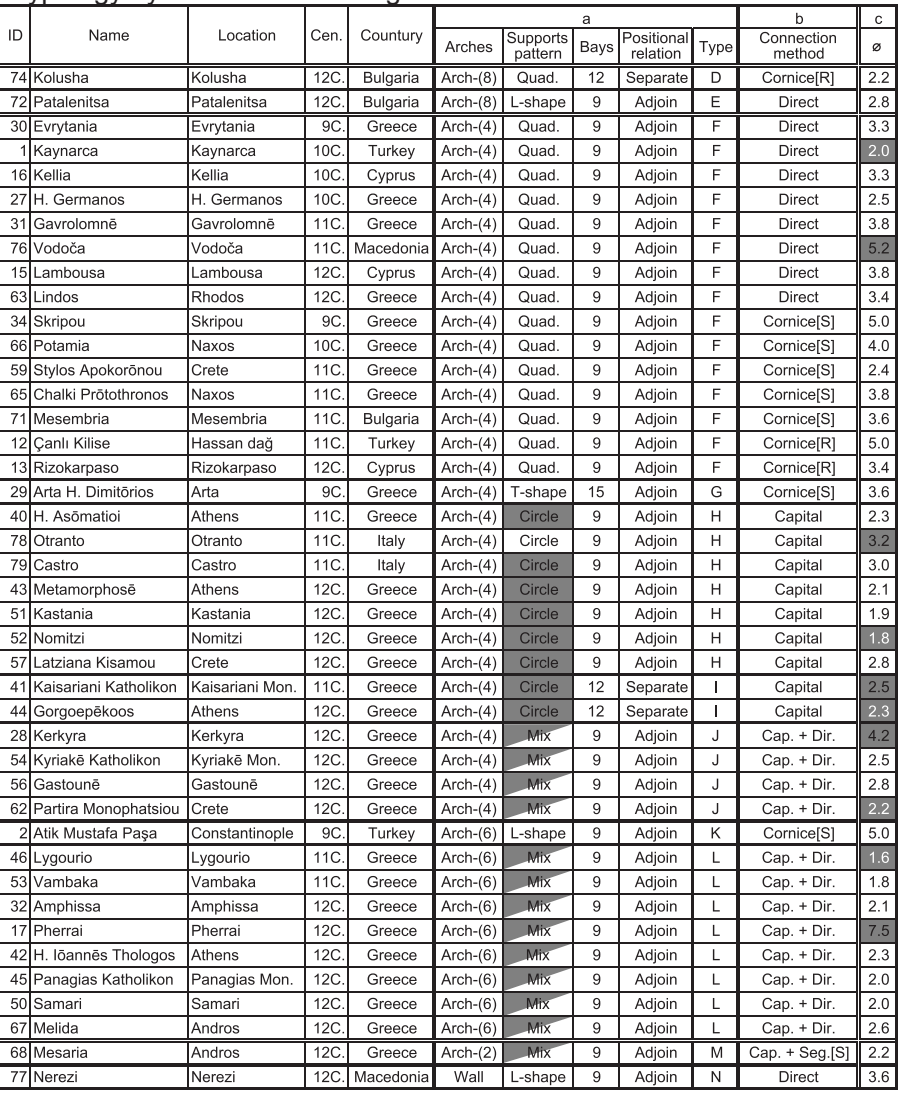

intrados segment of the four supports, see Fig 10-c; Cornice[R]: Cornices round between all supports and arches, see Fig 10-d, Step: Sizes of section of arches and supports are different; Cap. + Dir.: Capitals are on the western supports and arches and eastern supports connect directly; Cap. + Cor.[S]: Capitals are on the western supports and cornices are on the spring point of intrados segment of eastern supports); of the dome $[\mathrm{m}]$ (Bolded number with grey indicates the largest diameter of the dome in each type, white number with grey indicates the smallest diameter of the dome in each type, and '?' is the unknown of the diameter, assuming the type has more than one church)
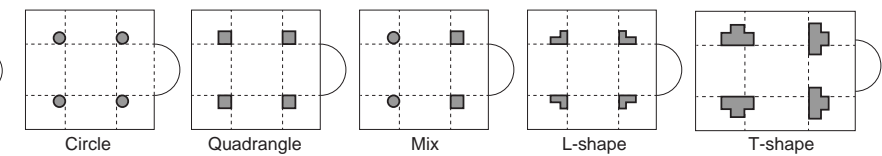

Fig. 7 Horizontal section patterns of supports

Fig. 6 Arrangement of the arches and number of the highest arches

\section{堂として仮定できる（Fig. 4）。}

上述の内接十字型の定義に基づいて、中期ビザンツ内接十字型教 会堂を可能な限り網羅的に抽出した結果 ${ }^{21)} 、 154$ の遺構が確認され た。これらは、ビザンツ文化圈全土に分布していることから（Fig. 5)、本稿で用いる内接十字型の用語概念は、地域的に限定されるも のではなく、当該文化圈における一建築形式として捉えることが可 能である。そのうち、既往研究および現地調査によって上部架構を 識別するに足る情報を得られた遺構は 84 棟であるが（Fig. 5:1～84、

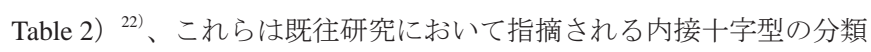
を網羅しており、かつ 154 の遺構と比較して地域的に大きな偏りは みられない。また検討対象遺構の創建年代をみると、内接十字型の 成り立ちを考察する上で特に重要と考えられる9〜10世紀のものに ついては、その8割以上を網羅している ${ }^{23)}$

\section{3. 内接十字型教会堂の分類}

内接十字型の架構構成に着目しつつ、内接十字型の成り立ちにつ いて考察するため、十字部の入隅に配置された隅部柱とその上部の
アーチ（以下、上部アーチ :Arches）によって構成される、十字部と コーナーベイ部の接続構面の形態的な特徵に着目し、以下のように 分類した。

まず、十字部とコーナーベイ部の接合・分節の違いを明確にする ため、接続構面における上部アーチの高さに着目すると、上部アー チの配列形式は以下のように大別できる ${ }^{24)}$ 。即ち、全ての上部アー チが全て同じ高さに配列されるArch-(8) 型 (Fig. 6-a)、隅部柱から南 北方向および西側へ架かる計六本の上部アーチが一番高くなる Arch(6) 型（Fig. 6-b)、隅部柱から南北方向に架かる計四本の上部アーチ が一番高くなるArch-(4) 型（Fig. 6-C)、西側の隅部柱から南北へ架か る上部アーチが最も高くなるArch-(2) 型（Fig. 6-d)、西側の隅部柱の 上には上部アーチが無く、東側の隅部柱から南北方向へ架かる上部 アーチが最も高くなるWall 型（Fig. 6-e）である。

また、隅部柱の断面は、円形、矩形、 L 字形 ${ }^{25}$ 、 $\mathrm{T}$ 字形に弁別可 能であり、ドームベイの各隅に配された 4 本の組み合わせをみる と、全ての隅部柱が円形となるもの、全ての隅部柱が矩形となるも の、西側の 2 本が円形となり、東側の 2 本は矩形となるもの、全て 


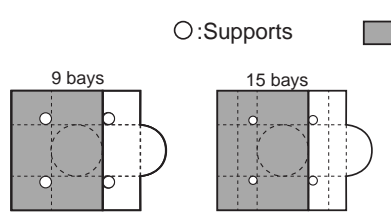

Dome-bay adjoins Bema

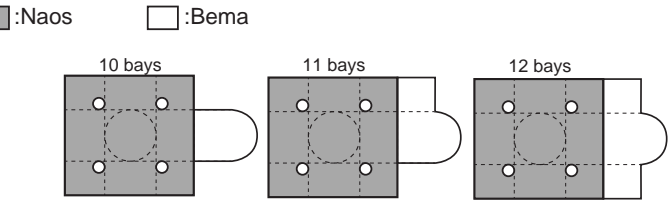

Dome-bay separates from Bema

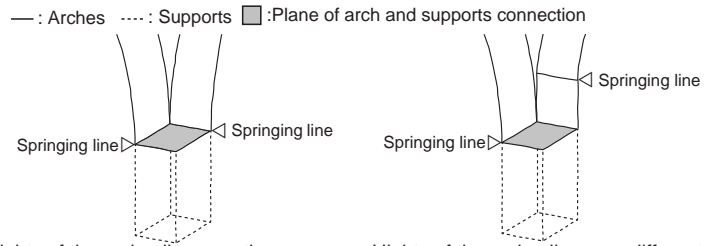

Hights of the spring lines are the same Hights of the spring lines are different Fig. 9 Plane of connection for arches and supports

Fig. 8 Relationship between bema and dome bay, according to the number of bays

L 字形となるもの、および全て T 字形となるものであり、これらを それぞれ Circle 型、Quadrangle 型、Mix 型、L-shape 型、および T-shape 型とする (Fig. 7)。

主部のベイ数は 9 〜 12 ベイおよび 15 ベイのものがある。ベイ数 とナオス・ベマの境界位置をみると、 9 ベイおよび 15 ベイとなる場合、 ナオスとベマの境界が東側の隅部柱の位置となりベマがドームベイ と接する。一方 $10 １ 2$ ベイとなる場合、ナオスと心゙マの境界は東 ベイの東端となりべマはドームベイと離れている（Fig. 8)。

以上の分類より、対象遺構を整理したものが Table 2-aである。表 から 14 の類型を識別でき、それらにA から N の記号を付した。各 類型の具体的な分類結果について、上部アーチの配列、隅部柱の断 面形状、ドームベイとベマの関係性および該当する遺構数の順に以 下に示す。

Type-A : Arch-(8) 型、Circle 型、ベマがドームベイと分離（22 棟） Type-B : Arch-(8) 型、Circle 型、ベマがドームベイと接続（14 棟） Type-C : Arch-(8) 型、Quadrangle 型、ベマがドームベイと接続(6棟) Type-D : Arch-(8) 型、Quadrangle 型、ベマがドームベイと分離(1 棟) Type-E : Arch-(8) 型、L-shape 型、ベマがドームベイと接続（1 棟） Type-F : Arch-(4) 型、Quadrangle 型、ベマがドームベイと接続(15棟) Type-G : Arch-(4) 型、T-shape 型、ベマがドームベイと接続（1 棟） Type-H : Arch-(4) 型、Circle 型、ベマがドームベイと接続（7 棟） Type-I : Arch-(4) 型、Circle 型、ベマがドームベイと分離（2 棟） Type-J : Arch-(4) 型、Mix 型、ベマがドームベイと接続（4 棟） Type-K : Arch-(6) 型、L-shape 型、ベマがドームベイと接続（1 棟） Type-L : Arch-(6) 型、Mix 型、ベマがドームベイと接続（8 棟） Type-M: Arch-(2) 型、Mix 型、ベマがドームベイと接続（1 棟） Type-N : Wall 型、L-shape 型、ベマがドームベイと接続（1 棟）

\section{4. 架構形式からみた内接十字型教会堂の特質と成り立ち}

本章では、抽出された各類型における形態と構法との関係性に注 目してそれぞれの特徵を明らかにし、架構としての特質から内接十 字型の成り立ちについて考察を行う。

中期ビザンツ内接十字型教会堂における壁や上部アーチの構法は、 表層の壁積みに使用寸る材料に切石、野石、レンガなどの違いはあ るものの、ほぼ共通しており、石とレンガ、もしくはそのいずれか、 をモルタルを使用しつつ積んで壁面とし、両面の間に芯となるモル タルと荒石を充填している ${ }^{26)}$ 。隅部柱の構法では、採石場から切り 出して柱状に成形した石材を用いるものと壁や上部アーチと同様の 構法によって構築するものの二つがあげられる。対象遺構における 隅部柱の断面形状は、前者では全て円形となり ${ }^{27)}$ 、後者では矩形を 中心に L 字形・T 字形・円形のものもみられる ${ }^{28)}$ 。このように、隅 部柱は、その形態によって構法が異なるものの、その上に載る上部
アーチ自体の構法は一様であり、配列形式のみ異なる。上部アーチは、 Nerezi (77) を除き、一つの隅部柱の上には直交関係となる二つの上部 アーチが配される。そこで、二つの上部アーチの起拱点が異なる高 さの場合、アーチの高さにより断面が異なるため、低い方の上部アー チの起拱点において上部ア一チ接合部の断面形状を求めた (Fig. 9)。 隅部柱と上部アーチとの接合形式と構法との関係性をみると、柱状 に石材を切出して隅部柱とする場合、円形断面の隅部柱と矩形断面 の上部アーチの間に柱頭がある。一方、隅部柱と上部アーチが同じ 構法である場合、円形断面の隅部柱と矩形断面の上部アーチの間に 柱頭がある Otranto (78) を除き、断面形状そのものは隅部柱と上部アー チとで等しい上で、上部アーチと隅部柱とを直接接続するものと見 切縁を介して接続するものとにわけられる。隅部柱と上部アーチと の接合形式と各類型との関係性をみると Type-C · F を除いた各類型 では一つの接合形式と対応しているのに対し、Type-C ・ F では三つ の接合形式が認められる。これらをまとめたものが Table 2-b である。

このように内接十字型の教会堂では、十字部とコーナーベイ部と の接続構面の架構構成に多様なものがみられるにも拘らず、既往研 究はこのような多様な架構構成を等閑視して内接十字型として一括 りにしてきた。しかし、十字部とコーナーベイ部という二つの空間 がどのように接続されているかという観点からは、十字部とコーナー ベイ部の接続構面の架構形式の実態を検討する必要があると考えら れる。そのため、以下では上部アーチの配列形式ごとに十字部とコー ナーベイ部の接続構面の形態と構法との関係性について考察する。 なおこの際に、中央のドームの大きさが開口部の形式を左右した可 能性も考えられるため、対象遺構のドーム径について Table 2-c に縓 めている。

\section{Arch-(8) 型（Type-A-E）:}

Type-A・B では、前者の主部のベイ数は 12 であり、後者の主 部のベイ数は 9 つであるものの、隅部柱が Circle 型である点、柱 頭が隅部柱と上部アーチの間にある点（Fig. 10-a）、隅部柱が上部 アーチと異なる構法で構築されている点で共通している。従って、 Type-A・B は十字部とコーナーベイ部の接続構成に関して同一であ る。各遺構のドーム径は、Type-A では最大で $7 \mathrm{~m}$ 、最小で $2.7 \mathrm{~m}$ で あり、Type-B では最大のドーム径は $4.1 \mathrm{~m}$ 、最小のものは $1.5 \mathrm{~m}$ で ある。続いて、Type-Cでは、主部のベイ数は 9 つであり、隅部柱 はQuadrangle 型かつ隅部柱と上部アーチは同じ構法ある。遺構の うち最大のドーム径は $3.8 \mathrm{~m}$ 、最小のドーム径は $1.3 \mathrm{~m}$ である。隅部 柱と上部アーチの接合形式をみると、以下のように弁別できる。即 ち、Zemen (73)のように隅部柱と上部アーチを直接接続するもの (Type-C-Direct: Fig. 10-b) ${ }^{29)}$ 、Kalaman (11)のように、隅部柱と上 部の接合部のうち、上部アーチの内輪面の夕見切縁が存在している もの (Type-C-Cornice[S ]: Fig. 10-c)、Schēmatari (30)のように、隅 


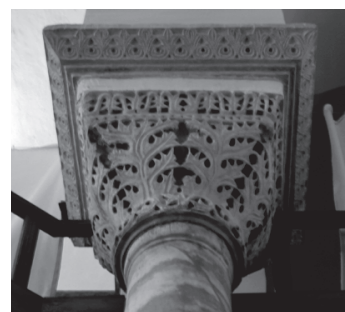

a. Capital (Trilye (10))

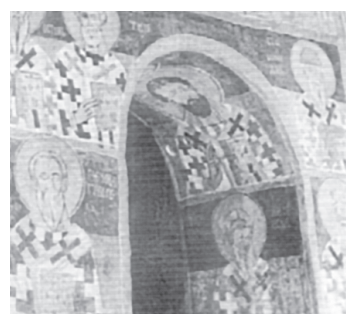

b. Direct (Zemen (73))

(Photo by Mavrodinova, L.)

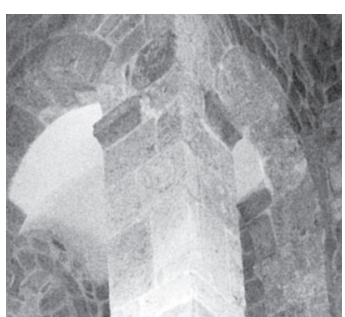

c. Cornice[S] (Kalaman (11))

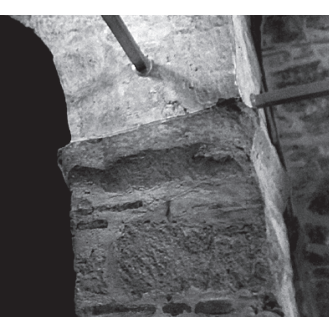

d. Cornice[R]

(Schērmatari (36))

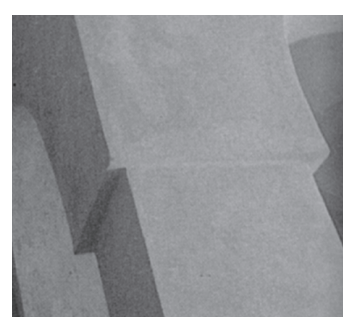

e. Step (Rossano (81)) (Photo by Cavallo, B et al.)

Fig. 10 Connection methods for arches and supports

部柱と上部アーチの接合部で見切縁が一周回っているもの（Type-CCornice[R ]: Fig. 10-d)、およびRossano (81) のように、隅部柱の断面 と上部アーチの起拱点における水平断面が異なる大きさになるもの (Type-C-Step: Fig. 10-e) である ${ }^{30)}$ 。Type-D の K olusha (74) は、隅部 柱が Quadrangle 型であり、直径 $2.2 \mathrm{~m}$ のドームを有している。主部 のベイ数は 12 個、隅部柱と上部アーチが同じ構法であり、Schēmatari (30) などと同様に、隅部柱と上部アーチの接合部に見切縁が一周回っ ている。従って、主部のベイ数こそ異なるものの、十字部とコーナー ベイ部の接続構成に関してKolusha (74) は Type-C-Cornice[R ] と同一 と見做せる。これらに対し、Type-E の Patalenitsa(72)の教会堂では、 主部が 9 ベイである点においてはType-B やType-C と共通している ものの、隅部柱は他の遺構ではみられない L-shape 型であり、隅部 柱と上部アーチが直接接続しているものも Zemen (73) 以外の遺構で はみられない。

このように、Arch-(8) 型となる上部アーチ配列の遺構では、隅 部柱と上部アーチを直接接続するもの（Type-C-Direct: Zemen (73)、 Type-E: Patalenitsa(72)）および隅部柱と上部の接合部のうち、上 部アーチの内輪面のみ見切縁が存在するもの (Type-C-Cornice[S ]: Kalaman (11)）の遺構数はそれぞれ 1 棟ずつであり、隅部柱と上部 アーチを柱頭や見切縁、接合部の断面積の違いによって分節するも のが大多数を占めている。年代別には、隅部柱と上部アーチを異な る構法で構築する遺構（Type-A・Type-B） が検討対象年代を通じて みられるのに対し、隅部柱と上部アーチを同じ構法で構築するもの ののうち、両者が見切縁などで分節される遺構 (Type-C-Cornice[R]• Type-C-Step・Type-D）は 11 世紀以降に出現し、両者が完全に分節 されない遺構（Type-C-Direct、Type-C-Cornice[S]、Type-E）は 12 世紀にのみみられる。また、主部が 12 ベイのものは検討対象年代を 通じて存在する一方、9ベイのものは 11 世紀以降にのみ確認される。 加えて、ドーム径は、9世紀よりみられる Type-A においては最大の ものがみられ、Type-B-E のそれぞれの類型における最大のドーム径 よりも大きなドームがすでに 9 世紀の Trilye (10) においてみられる。 従って、Arch-(8) 型では、10 世紀までは隅部柱と上部アーチとを異 なる構法で構築する遺構のみであったが、11 世紀以降では同じ構法 で構築する遺構もみられるようになる。隅部柱と上部アーチの接合 形式という点では、12 世紀にみられるそれぞれ 1 棟ずつの Type-CDirect、Type-C-Cornice[S]、Type-E を除き、隅部柱と上部アーチと を柱頭や見切縁などによって分節している点で共通している。その 上で、主部のべイ数以外の構成は同一である Type-A は Type-B に 先行してみられ、同様にType-C は Type-Dに先行している。加え て、同じ 11 世紀以降にのみみられる類型ではあるものの、Type-B
はType-C に先行している ${ }^{31)}$ 。即ち、隅部柱の断面形状とそれに伴 う構法こそ異なるものの、上部アーチの配列形式および上部アーチ と隅部柱が分節されている点で共通していることから、Type-A・B・ C-Cornice [R]・D は Type-A に端を発する一つの系統とも見做し得る。 また、後に出現した類型におけるドームの大きさは 9 世紀より存在 する Type-A よりも小さくなる傾向となっている。

\section{Arch-(4) 型 (Type-F-J ) :}

Type-F では主部は 9 つのベイより構成され、ベマとドームベイ が接する。隅部柱は Quadrangle 型であり、上部アーチと同じ構 法である。ドーム径が最大となるのはV Vodoča (76) であり $5.2 \mathrm{~m}$ 、最 小となるのは Kaynarca (1)の $2.0 \mathrm{~m}$ である。隅部柱と上部アーチの 接合形式は、大きく3つに弁別できる。即ち、Kaynarca (1) のよ うにZemen (73) 同様、隅部柱と上部アーチとを直接接続するもの (Type-F-Direct)、Potamia(66)のように、Kalaman (11) 同様、隅部柱 と上部アーチの接合部のうち、上部アーチの内輪面にのみ見切縁が 存在するもの (Type-F-Cornice[S ] ${ }^{32) 、 お よ ひ ゙ C ̧ a n l ı ~ K i l i s e ~(12) の よ ~}$ うに、Schērmatari (36) 同様、隅部柱と上部アーチの接合部で見切縁 が一周回っているものである (Type-F-Cornice[R])。続いて、3.6m のドームを有する A rta A. Dimitōrios (29) のみ該当する Type-G は、 15 のベイによって主部が構成され、ベマとドームベイが接する。隅 部柱はT-shape 型であり、上部アーチと同じ構法である。隅部柱 と上部アーチの接合部のうち、上部アーチの内輪面にのみ見切縁が

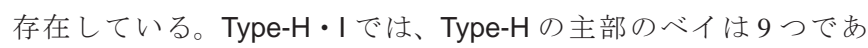
り、ベマとドームベイが接する一方、Type-Iの主部のベイは 12 で あり、ベマとドームベイが離れている。Type-Hのうちドーム径が 最大となるのは Otranto (78)の 3.2m、最小となるのは Nomitzi (52) の 1.8m であり、Type-Iの 2 棟のうち、K aisariani (41)のドーム径は $2.5 \mathrm{~m}$ 、 Gorgoepēkoos (44) のドーム径は $2.3 \mathrm{~m}$ である。両類型共に隅部柱は Circle 型であり、Otranto (77) を除き切出した石材を柱としているた め、上部アーチとは異なる構法である。上部アーチの接合部の断面 形状は矩形であり、隅部柱との間には Trilye (10) 同様に柱頭がある。 従って、主部のベイ数こそ異なるものの、隅部柱が Circle 型である 点、隅部柱と上部アーチが異なる構法となっている点、それに伴っ て隅部柱と上部アーチが分節されていると捉え得る点から、Type-H と Type-Iは十字部とコーナーベイ部の接続構成として同一といえる。 最後にType-Jでは、主部は 9 つのベイから構成され、ベマとドーム ベイが接する。隅部柱はＭix 型である。ドーム径が最大となるのは、 ドーム径が $4.2 \mathrm{~m}$ の K erkyra (28) であり、最小となるのは、 $2.2 \mathrm{~m}$ とな る Partira M onophatsiou (62) である。隅部柱と上部アーチの接合形式 をみると、東側では隅部柱と上部アーチとを直接接続させているの 
Table 3 The number of the churches in each type, by century

\begin{tabular}{|c|c|c|c|c|c|c|c|c|c|c|}
\hline Type & Arches & Supports pattern & Positional relation & $\begin{array}{l}\text { Construction methods for } \\
\text { arches and supports }\end{array}$ & $\begin{array}{l}\text { Patterms for connection of } \\
\text { arches and supports }\end{array}$ & 9C. & $10 \mathrm{C}$. & $11 \mathrm{C}$. & 12C. & Sum. \\
\hline A & Arch-(8) & Circle & Separate & Different & Discrete & 2 & 8 & 5 & 7 & 22 \\
\hline B & Arch-(8) & Circle & Adjoin & Different & Discrete & & - & 5 & 9 & 14 \\
\hline C-Cornice $[\mathrm{R}]$ & Arch-(8) & Quadrangle & Adjoin & Same & Discrete & & & 1 & 2 & 3 \\
\hline C-Step & Arch-(8) & Quadrangle & Adjoin & Same & Discrete & & & 1 & -1 & 1 \\
\hline $\mathrm{D}$ & Arch-(8) & Quadrangle & Separate & Same & Discrete & & & 7 & 1 & 1 \\
\hline C-Cornice[S] & Arch-(8) & Quadrangle & Adjoin & Same & Semi-continuing & - & - & - & 1 & -1 \\
\hline C-Direct & Arch-(8) & Quadrangle & Adjoin & Same & Continuing & - & - & - & 1 & $\rightarrow$ \\
\hline $\mathrm{E}$ & Arch-(8) & L-shape & Adjoin & Same & Continuing & & & - & 1 & 1 \\
\hline F-Direct & Arch-(4) & Quadrangle & Adjoin & Same & Continuing & 1 & 3 & 2 & 2 & 8 \\
\hline F-Cornice[S] & Arch-(4) & Quadrangle & Adjoin & Same & Semi-continuing & 1 & 1 & 3 & & 5 \\
\hline G & Arch-(4) & T-shape & Adjoin & Same & Semi-continuing & 1 & & - & - & 1 \\
\hline F-Cornice $[R]$ & Arch-(4) & Quadrangle & Adjoin & Same & Discrete & & & 1 & 1 & 2 \\
\hline $\mathrm{H}$ & Arch-(4) & Circle & Adjoin & Different & Discrete & - & - & 3 & 4 & 7 \\
\hline 1 & Arch-(4) & Circle & Separate & Different & Discrete & - & 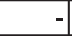 & 1 & 1 & 2 \\
\hline $\mathrm{J}$ & Arch-(4) & Mix & Adjoin & Different + Same & Discrete + Continuing & 7 & - & 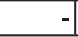 & 4 & 4 \\
\hline$\overline{\bar{K}}$ & Arch-(6) & L-shape & Adjoin & Same & Continuing & 1 & & - & & 1 \\
\hline $\mathrm{L}$ & Arch-(6) & Mix & Adjoin & Different + Same & Discrete + Continuing & -1 & 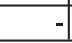 & 2 & 6 & 8 \\
\hline $\mathrm{M}$ & Arch-(2) & Mix & Adjoin & Different + Same & $\begin{array}{l}\text { Discrete + Semi-continuing } \\
\end{array}$ & - & -1 & - & 1 & 1 \\
\hline$\overline{\mathrm{N}}$ & Wall & L-shape & Adjoin & Same & Continuing & & & 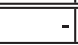 & 1 & 1 \\
\hline Sum. & & & & & & 6 & 12 & 24 & 42 & 84 \\
\hline
\end{tabular}

Note on table 3: Arches: The arrangement of the arches and number of the highest arches (see Fig. 6); Supports pattern: Patterns of horizontal sections of supports (see Fig. 7) ; Positional relation: Positional relation of bema and dome bay (see Fig. 8);

Construction methods for arches and supports (Different: the construction methods for arches and supports are different, Same: the construction methods for arches and supports are the same, Different + Same: construction methods for arches and supports are different in western part and the same in eastern part); Patterns for connection of arches and supports (Discrete: capitals or cornices are between arches and supports, Semi-continuing: cornices are between arches and supports on the intrados of the arches, Continuing: arches and supports are connected directly, Discrete + Continuing: capitals are between western supports and arches, and eastern arches and supports are connected directly, Discrete + Semi-continuing: capitals are between western supports and arches, and cornices are between arches and supports on the intrados of the arches),

Numbers indicate the number of the churches in each century, '-' means there was no church of that type in that century.

に対し、西側では柱頭が両者の間に存在している。

このように、Arch-(4) 型では、Type-Iを除いてべマとドームベイ が接しており、類型間の差異は隅部柱の断面形状によっている。隅 部柱と上部アーチとは、10世紀までは同じ構法によって構築され る (Type-F・G) 一方、11 世紀以降では両者を異なる構法で構築す るもの (Type-H・|・J) もみられるようになる。また、後に出現し た類型におけるドームの大きさは 9 世紀より存在する Type-F よりも 小さい傾向になっている。加えて、隅部柱と上部アーチとの接合形 式をみると、両者が直接接続される形式の遺構は検討対象年代を通 じてみられ (Type-F-Direct・Type-Jの東隅部柱)、上部アーチの内 輪面にのみ見切縁が存在する遺構は 9 世紀から 11 世紀までみられる (Type-F-Cornice[S]・Type-G)。一方、見切縁ないし柱頭によって隅 部柱と上部アーチを分節する遺構は 11 世紀以降でのみ確認される (Type-F-Cornice[R ] - Type-H・Type-I ・ Type-J の西隅部柱)。従って、 Arch-(4) 型となる類型では、隅部柱と上部アーチが同じ構法となり、 かつ隅部柱と上部アーチが直接接続する形式、ないし隅部柱と上部 アーチの内輪面にのみ見切縁が存在する形式が出現した後に、隅部 柱と上部アーチが同じ構法であるものの、両者を見切縁によって分 節する形式や隅部柱と上部アーチが異なる構法である形式が出現し ている。即ち、もともと隅部柱と上部アーチが分節されない形式で あったものが、時代が降ると共に隅部柱と上部アーチが分節される 形式もみられるようになったといえる。また、後に出現した類型に おけるドームの大きさは 9 世紀より存在する Type-F・G よりも小さ くなる傾向となっている。

Arch-(6) 型 (Type-K・L) :

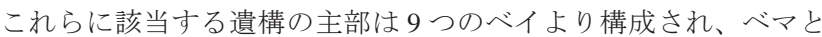

ドームベイが接する。Type-K となる唯一の例である 9 世紀の A tik M ustafa Pașa (2) ではドーム径は 5.0m であり、隅部柱と上部アーチ とを同じ構法で構築している。隅部柱は L-shape 型であり、隅部柱 と上部アーチとの接合部のうち、上部アーチの内輪面にのみ見切縁 が存在している。一方 Type-Lでは、隅部柱は Mix 型であり、西側 の隅部柱と上部アーチは異なる構法である一方、東側の隅部柱と上 部アーチは同じ構法である。隅部柱と上部アーチの接合形式をみる と、西側では隅部柱と上部アーチの間に柱頭があるのに対し、東側 では隅部柱と上部アーチが直接接続している。最大となるドーム径 は Pherrai (17) の 7.5mであり、最小となるドーム径は Lygourio (46) の $1.6 \mathrm{~m}$ である。また当該類型の遺構の創建年代をみると、Lygourio (46) と Vambaka (53) が 11 世紀創建であり、他は 12 世紀創建である。 このように Type-K と Type-L の遺構では、隅部柱の断面形状や隅部 柱と上部アーチにおける構法の同異点、および隅部柱と上部アーチ との接合形式が異なり、創建年代にも隔たりの認められることから、 上部アーチの配列は同じであるものの、両者の関係性は薄いものと 推察される。

\section{Arch-(2) 型 (Type-M) • Wall 型 (Type-N) :}

Type-M・N に該当する遺構の主部は共に 9 つのべイによって構成 され、ベマとドームベイが接する。該当する遺構は共に 1 棟ずつか つ 12 世紀創建である。Type-M となるドーム径 $2.2 \mathrm{~m}$ の M esaria (68) では、隅部柱は Mix 型であり、西側の隅部柱と上部アーチは異なる 構法である一方、東側の隅部柱と上部アーチは同じ構法である。隅 部柱と上部アーチの接合形式をみると、西側では隅部柱と上部アー チの間に柱頭があるのに対し、東側では上部アーチの内輪面のみ見 切縁がある。一方 Type-N の N erezi (77) では、ドーム径は 3.6m であり、 
隅部柱は L-shape 型である。隅部柱と上部アーチは同じ構法であり、 両者は直接接続している。

以上より、各世紀ごとの類型に該当する遺構数とそれぞれの類型 における架構構成について䌕めたものが Table 3 であり、9〜 12 世紀 を通じてみられるのは上部アーチの配列が Arch-(8) 型とArch-(4) 型 となる場合のみであった。それぞれの上部アーチ配列において 9 世 紀にみられる、Type-A と Type-F・G の架構構成を比較すると、上部 アーチの配列形式のみならず、隅部柱の断面形状や隅部柱と上部アー チにおける構法の同異や接合の形式、ベマとドームベイとの位置関 係においても違いがみられることから、両者の起源が異なる蓋然性 は高いものと判断される。また内接十字型教会堂において一般的と されるドームの直径は 3〜 5m であり ${ }^{33)}$ 、Arch-(8) 型とArch-(4) 型の うち 9 世紀からみられる Type-A と Type-F がそれぞれドーム径が $5 \mathrm{~m}$ 以上の遺構および $3 \mathrm{~m}$ 未満のものも有することを鑑みれば（Table 4)、 それぞれにおける架構構成の違いはドーム径に依存するものではな かったものと推察される。

Arch-(8) 型のうち、9 世紀にみられる Type-A の架構構成をみると、 9 ベイ部とナオスとが一致し、ドームがナオスの中心に架かり、ドー ムベイの隅部には四本の円柱を配置し、円柱の上部には柱頭を介し て同じ高さのアーチをナオスの端部へ架けている。従って、十字部 とコーナーベイ部との開口に東西方向と南北方向とで違いはみられ ない。このさらに東にべマは位置している。即ち、Type-A では上述 の構成によってドームを中心とした点対称が付与され、結果として ドームベイの求心性が獲得されていると見做せ、Type-Dについても、 隅部柱の断面形状が矩形であること以外は同様であるといえる。同 様に Type-B・C-Cornice[R]では、9ベイ部において同じ断面形状の 隅部柱を配置し、上部アーチを全て同じ高さとし、隅部柱と上部アー チとは柱頭ないし見切縁で分節されている。従って、Type-A-D の 9 ベイ部は、集中形式に準じた構成によって、十字部とコーナーベイ 部を接続したものであり、Type-A・D ではその東にベマを附設して いるといえる。また特にType-A・B では、隅部柱と上部アーチとは 単に柱頭によって分節されているだけでは無く、構法的にも違いが みられ、隅部柱とその上に載ったアーチという構成が構法としても 明示されている。

一方、Arch-(4)型のうち、9世紀にみられるType-F-Direct・ Type-F-Cornice[S]・Type-G の架構構成をみると、ドームベイと ベマとは接しており、従って 9 ベイ部はべマとナオスの双方より 構成される。ドームベイの隅部には四本の矩形 (Type-F-Direct・ Type-F-Cornice[S]）ないし T 字形 (Type-G) の柱を配置し、これら の柱と上部アーチとは直接接続 (Type-F-Direct)、ないしは内輪面の み見切縁が存在している (Type-F-Cornice[S]・Type-G)。上部アーチ は南北方向に架かるものは全て同じ高さであり、かつ東西方向に架 かる上部アーチよりも高い。加えて、隅部柱と上部アーチとは同じ 構法で構築される。従って、これらの類型では、構法的な同一性に より隅部柱から上部アーチ、およびその上の垂れ壁まで一体的に見 做すことが可能であり、十字部とコーナーベイ部との接続構成にお いて、開口の低い東西方向の構面と開口の高い南北の構面となるこ とから、東西方向と南北方向で異なる方向性を有すると言える。ま
Table 4 Distribution of churches according to type, by diameter of dome

\begin{tabular}{|c|c|c|c|c|c|c|c|c|c|}
\hline \multirow{2}{*}{ Arches } & \multirow{2}{*}{ Type } & \multicolumn{8}{|c|}{ Diameter in metres } \\
\hline & & $\sim 1$ & $\sim 2$ & $\sim 3$ & $\sim 4$ & $\sim 5$ & $\sim 6$ & $\sim 7$ & $\sim 8$ \\
\hline \multirow{5}{*}{ Arch-(8) } & $\mathbf{A}$ & & & 0 & 0 & 0 & 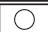 & 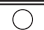 & \\
\hline & B & & 0 & 0 & 0 & 0 & & & \\
\hline & C & & 0 & 0 & 0 & & & & \\
\hline & D & & & 0 & & & & & \\
\hline & E & & & 0 & & & & & \\
\hline \multirow{5}{*}{ Arch-(4) } & $\mathbf{F}$ & & 0 & 0 & 0 & 0 & 0 & & \\
\hline & G & & & & 0 & & & & \\
\hline & $\mathrm{H}$ & & 0 & 0 & 0 & & & & \\
\hline & $I$ & & & 0 & & & & & \\
\hline & $\mathbf{J}$ & & 0 & & & 0 & & & \\
\hline \multirow{2}{*}{ Arch-(6) } & $K$ & & & & & 0 & & & \\
\hline & $\mathbf{L}$ & & 0 & 0 & & & & & 0 \\
\hline Arch-(2) & $M$ & & & 0 & & & & & \\
\hline Wall & $\mathbf{N}$ & & & & 0 & & & & \\
\hline
\end{tabular}

た、いずれも隅部柱と上部アーチとを同じ構法で構築しており、両 者は直接接続されるか、もしくは上部アーチの内輪面にのみ見切縁 が存在している。その点で、Type-A のように隅部柱と上部アーチと を明確に分節するものとは一線を画すものであり、隅部柱と上部アー チとを一体的なものとして見做すことができる。即ちType-F-G で は、Type-A のように隅部柱の上にアーチを載せたのでは無く、教会 堂内部の東西方向に配された壁にアーチで開口を設けることによっ て生じた可能性を示唆し得る。但し、このように上部アーチの配列 形式ごとに架構構成の違いが明確に窥えるのは 9 10世紀のみであ り、11 世紀以降、類型の数が増加する一方で個々の遺構におけるドー ム径が小さくなる傾向がみられるようになるつれて、Arch-(4) 型にお いても隅部柱と上部アーチを同じ構法のもと直接接続する遺構が全 体に占める割合は減り、隅部柱と上部アーチを別の構法で構築する 類型や隅部柱と上部アーチとを見切縁で分節する類型が多数を占め るようになる。

以上より、一般に内接十字型と呼称される教会堂建築について、 異なる起源より発したと考えられる二つの架構構成が確認された。 それぞれの十字部とコーナーベイ部と接続構面についてみてみると、 一方は同じ高さの上部アーチ配列によって、ドームを中心とした集 中形式の教会堂に準じた構成となるものとして捉えられるのに対し、 もう一方は、東西方向と南北方向で異なる高さの上部アーチ配列と なるものとして捉えられた。それぞれの架構に着目すると、前者が 柱の上部にアーチを載せたものと捉え得るのに対し、後者は東西方 向に配された壁にアーチを用いて開口を設けたものと捉え得る。但 し、後者の架構構成となる遺構が内接十字型全体に占める割合は時 代が降るに連れて減少し、11 世紀以降では柱の上部にアーチを載せ たものと捉え得る架構構成の遺構が多数を占めるようになる。

\section{5. まとめ}

中期ビザンツ文化圈における内接十字型教会堂建築について、十 字部とコーナーベイ部の接続構面における架構構成を中心に分類を 行った。既往研究における議論が、しばしば立体的な特徽を見過ご し、平面的な特徴を中心にされていた点を鑑みて、本稿では隅部柱 の断面形状、上部アーチの配列形式、隅部柱と上部アーチの接合形 
式および主部のベイ数を分類項目として類型化を行い、14 の類型を 抽出した。類型間を通じての架構形式の類似性によって、これら類 型は大きく二つの架構構成に弁別可能であり、一つは上部アーチを 同じ高さに配列し、かつ隅部柱と上部アーチとを分節するものであ り、もう一つは南北方向に架かる上部アーチを東西方向に架かる上 部アーチよりも上部に配置し、かつナオスとべマの境界が東側の隅 部柱の位置と一致するものである。

前者は、隅部柱の上に同じ高さの上部アーチを配列することによっ て集中形式の教会堂に準じた構成を実現しているものとして捉えら れ、隅部柱と上部アーチとを分節している点から、教会堂の架構形 式の説明としては、柱の上部にアーチを載せる形式と見做し得る。 もう一方は、隅部柱から南北方向へ架かるアーチと比較して東西方 向に架かるアーチが低いものであり、東西方向と南北方向で異なる 方向性を有した構成と見做せ、隅部柱と上部アーチとが分節されず、 かつ両者を同じ構法で構築している点から、壁にアーチを用いて開 口を設ける形式として見做し得る。これら二つの架構構成は中期ビ ザンツ帝国を通じて認められるものの、後者の架構構成は時代が降 るに連れて、全体に対する割合が減少し、11 世紀以降では柱の上部 にアーチを載せる遺構が大多数を占めるようになった。

このような架構構成による分類から、現在内接十字型と呼称され る教会堂建築は、平面的な類似性が認められるものの成り立ちの異 なる少なくとも二つの系統の建築形式を総称したものと考えること ができる。

\section{注}

1) Georgije Ostrogorski, History of Byzantine State, trans. J oan Hussey, Rev. ed. (New B runswick: Rutgers University Press, 1969)，230，304. 例えば、王の改宗に伴う ブルガリアのキリスト教化は8 864 年、ロシアのキリスト教化は 989 年である。

2) Cyril Mango, ByzantineArchitecture(1978; repr., Milan: Electa Editrice, 1985), 9.

3) Sophia Kalopissi-Verti and Maria Panayotidi-Kesisoglou, eds., Multilingual Illustrated Dictionary of Byzantine Architecture and Sculpture Terminology (Herakleion: Crete University Press, 2010), 378. 本稿における内接十字型とは、カロピシ 一ヴェルティらによる語句の定義を参考に、英語におけるCross-in-square, cross-inscribed (inscribed-cross), quincunx とそれに対応する église en croix inscrite avec coupole (フランス語)、K reuzkuppelkirche（ドイツ語）、 $\sigma \tau \alpha v-$

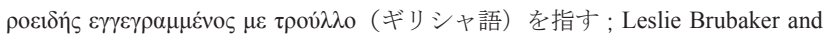
John Haldon, Byzantium in the Iconoclast Era c. 680-850: A History (Cambridge: Cambridge University Press, 2011), 300; Robert Ousterhout, Master Builders of Byzantium (Princeton: Princeton University Press, 1999), 17; Cyril Mango and Ihor Ševčenko, "Some Church Buildings on the Sea of Marmara," Dumbarton Oaks Papers 27 (1973): 264. 上部架構まで現存する内接十字型として最も古い教会堂 は、800 年頃に創建されたTrilyeの教会堂とされる。ただし、基礎部分の み残る遺構として、小アジアの沿岸部 Side の Church H（8 世紀末）および Trilye の教会堂の近くに位置する M egas A gros 修道院の聖堂 (780 年頃) が あげられる。

4) Richard Krautheimer, Early Christian and Byzantine Architecture, 4th rev. (New Haven: Yale University Press, 1986), 540.

5) Josef Strzygowski, Kleinasien, ein Neuland der Kunstgeschichte [Asia Minor, a New Land of Histry of Art (in German)] (Leipzig: J. C. Hinrichs, 1903), 132-35; た だし、後にストゥルツゴフスキーは、内接十字型をアルメニアよりもたら されたものとしている。Cf. Josef Strzygowski, Die Baukunst der Armenier und Europa [Buildings of Armenians and Europa (in German)] (Vienna: Anton Schroll, 1918), 2:845-54.

6) Gabriel Millet, L'école grecque dans l'achitecture byzantine [The Greek School of Byzntine Architecture (in French)] (Paris: Ernest Leroux, 1916), 54-94.

7) Dorothea Lange, "Theorien zur Entstehung der byzantinischen Kreuzkuppelkirche," [Theiries on the Origin of Byzantine Cross-in-Square Church (in German)] Archi- teutura 16 (1986): 93-113. ランゲはドームを有した矩形外形の教会堂の形式 として、ドーム附設バシリカおよびクロス・ドームド形式をあげている。

8) Robert Ousterhout, “An Apologia for Byzantine Architecture," Gesta 35, no. 1 (1996): 23-35.

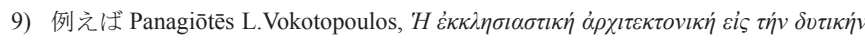

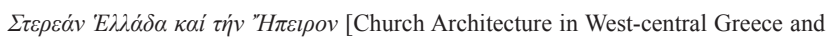
Epiros (in Greek)] (Thessaloniki, Kentron Byzantinōn Ereunōn, 1975) など。

10) Charalambos Bouras, "Originality in Byzantine Architecture," in Mélanges JeanPierre Sodini, ed. François Baratte et al. (Paris: Association des Amis du Centre d'Histoire et Civilisation de Byzance, 2005), 100. 例えば、ブラスは既往研究に おいて、特に芸術的な側面から、不当なまでにコンスタンティノープルの 建築に重点が置かれてきたことを指摘している; Robert Ousterhout, The Byzantine Monuments of the Evros/Meriç River Valley, (Thessaloniki: European Center for Byzantine and Post-Byzantine Monuments, 2007), 49-84. オスターフートは Pherrai の教会堂とコンスタンティノープルの教会堂のみを比較対照してい るが、それ以外の場所の教会堂を比較対照から除外した理由については述 ベていない。

11) Krautheimer, Early Christian, 341. クラウトハウマーは内接十字型とは地方よ りコンスタンティノープルへ導入された建築形式であったとしている。

12) John Haldon, The Palgrave Atlas of Byzantine History (2005; repr., Basingstoke, UK: Palgrave M acmillan, 2010), 118-120. 1205 年における、中期ビザンツ帝国 最大版図（1025 年頃）は、ラテン帝国、ニカイア帝国、トレビゾンド帝国、 エピルス専制候国、モレア専制候国、シチリア王国、第二次ブルガリア帝国、 セルビア王国、ボスニア王国、ハンガリー王国、キプロス王国、キリキア・ アルメニア王国、アンティオキア公国、ルームセルジューク朝、アイユー ブ朝に分割されている。

13) Slobodan Ćurčić, Architecture in the Balkans: From Diocletian to Süleyman the Magnificent (New Haven: Yale University Press, 2010), 348-49. チュルチッチは、 セルビア王国や第二次ブルガリア帝国の台頭により、13 世紀後半以降のバ ルカン半島におけるビザンツ帝国の建築的な影響力は減少したことを指摘 している。

14) 使用した既往研究は以下の通りである。Krautheimer, Early Christian; Mango, Byzantine; Ćurčić, Balkans; Millet, L'école grecque; Anastsios Orlandos, "H

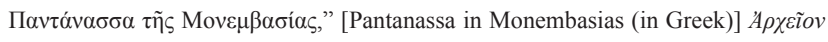

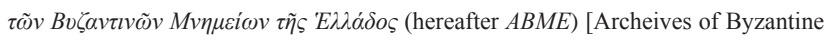

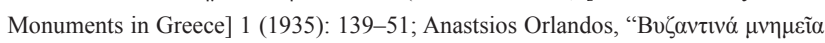

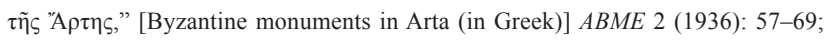

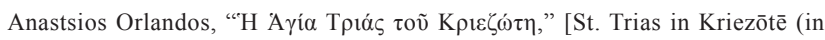
Greek)] ABME 5 (1939-1940): 3-16; Strzygowski, Kleinasien; Strzygowski, Die Baukunst.

15) ナオスと比較して、通常べマでは床面が一段高くなっている。

16) 既往研究では、内接十字型とされる教会堂について明確な定義が提示され ていない場合や提示された定義に当てはまらない教会堂を内接十字型と見 做している場合が多くみられる。このような場合、既往研究が内接十字型 と見做している教会堂の特徴を元に著者が想定した内接十字型の定義を推 測している。

17) Strzygowski, Kleinasien, 132-57. ストゥルツゴフスキーは他の研究者がク ロス・ドームド教会 (Cross-domed Basilica または Cross-domed Church) と して、内接十字型とは弁別している形式の教会堂についても内接十字型 (K reuzkuppelkirche) としている。しかし、このような用例はストゥルッ ゴフスキー以外にはみられず、かつクロス・ドームド教会という概念が ヴルフによって提示されたのが、ストゥルツゴフスキーが内接十字型と いう概念を提示したのとほぼ同時期であることから、本稿では、ストウ ルツゴフスキーの用例をビザンツ建築研究における内接十字型に関して のおおよその合意が形成される以前の用例と判断し、通常クロス・ドー ムド教会とされる教会堂については検討対象から外した。Cf. Oskar Wulff, Die Koimesiskirche in Nicäa und ihre Mosaiken nebst den verwandten kirchlichen Baudenkmälern [Koimesis Church in Nicaea and its Mosaics with Related Church Monuments (in German)] (Strassburg: J. H. E. Heitz, 1903), 98-108, 154-56.

18) Krautheimer, Early Christian, 295, 310-16, 340-41, 369-71, 376-77, 398-401, 517-18, 520. クラウトハイマーは隅部柱が矩形断面のものについて、一方で はホール・チャーチ (Hall church) と呼び、一方では内接十字型と呼んでい るものの、その弁別の基準に関しては不明である。また、隅部柱が L 字形 断面のものについてもクロス・ドームド教会 (Cross-domed Basilica または Cross-domed Church) と呼ぶ場合と内接十字型と呼ぶ場合がみられるものの、 
その違いは明確にしていない。

19) K alopissi-Verti, Dictionary of Byzantine, 378-87.

20)ミレーの理論は 20 世紀初頭に提起されたものであり、当時と比較して現在 ではビザンツ建築に関する知見が蓄積されたこと、またミレー自身は悉皆 的に当該地域の内接十字型教会堂を調査したわけでは無く、彼が当該地域 において代表的と見做した教会堂のみを検討の対象としている点を鑑みる と、ミレーの理論を無批判に踏襲すべきではないと判断した。

21) 中期ビザンツ内接十字型教会堂の選定にあたっては、以下の書籍を使用し

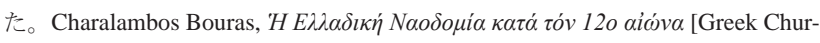
ches in 12th Century (in Greek)] (Athens: Emporikē Trapeza tēs Ellados, 2002);

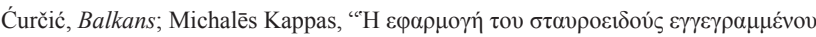

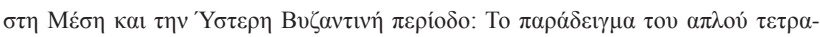

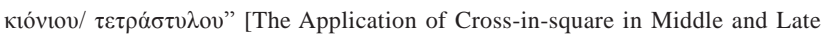
Byzantine Period: The Example of Simple Four-column/ four-pier (in Greek)] ( $\mathrm{PhD}$ diss., A ristotle University of Thessaloniki, 2009); K rautheimer, Early Christian; M ango, ByzantineArchitecture

22) 154 の遺構のうち、最低でも 28 棟については基礎部分のみ現存、もしくは 上部架構に改変が加えられており、上部架構まで検討可能なのは 126 棟で ある。なお、表中のID は対象遺構について、現在の国ごとかつ中期ビザ ンツ期の行政区画ごとに北から割り振ったものである。また、教会堂の呼 び方について、同じ名称となる場合や名称不明のものが存在することから、 本稿では通常遺構の存在する地名を使用し、同じ場所に複数の遺構が存在 する場合には、遺構の名称と地名の双方を使用している。

23) 上部架構まで検討可能と考えられる 126 棟について、各世紀ごとのうちわ けをみると、9 世紀が 6 棟、10 世紀が 14 棟、11 世紀が 40 棟、12 世紀が 66 棟であり、そのうち本論にて検討対象とする遺構は、 9 世紀が 6 棟 $(100 \%) 、$ 10 世紀が 12 棟 (85.7\%)、11 世紀が 25 棟 $(62.5 \%) 、 12$ 世紀が 41 棟 $(62.1 \%)$ であり、9〜 10 世紀創建の 20 棟中 18 棟（90\%）を検討対象としている（括 弧内の比率は、検討可能な内接十字型の遺構に対する本論で検討対象とす る遺構の割合を示す)。なお、推定創建年代が 9 。 10 世紀のように複数の 世紀にわたる遺構については、推定創建年代中で最も新しい世紀に創建さ れたものとしている。ただし、検討対象年代（800～1204 年）において 13 世紀は 4 年間しか無く、創建年ないし推定創建年が $1201 \sim 1204$ 年の範囲 にのみ収まる遺構は認められないことから、推定創建年代が 13 世紀にまで 亘る遺構の推定創建年代について煩雑さを避けるため 12 世紀とした。

24) 本稿における上部アーチの高さの違いとは、施工精度のばらつきなどによ るものでは無く、架構の状態から施工者が意識的に異なる高さにしたもの と判断できるものである。

25) 隅部柱の断面形状が $L$ 字形になるものの中には、アーチが架構されず十字 部とコーナーベイ部との間に直接的な開口が存在しない場合も含んでいる。

26) Jonathan Bardill, "Building Materials and Techniques," in Oxford Handbook of Byzantine Studies, ed. Elizabeth J effreys, John Haldon and Robin Cormack, (N ew York: Oxford University Press, 2008), 336. 内接十字型の確認される小アジア・ バルカン半島・イタリアおよびエーゲ海や地中海の島々では、ビザンツ建 築の構法は共通したものが使用されていたとされる。

27) 小規模な柱の場合、断面形状が円形では無く正多角形となるものもみられ るが、これらについても円形と見做した。

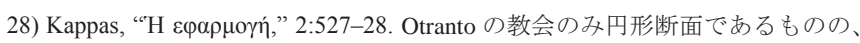
壁と同様の構法で隅部柱を構築している。

29) Liliāna Mavrodinova, Земенската иърква [Zemen Church (in Bulgarian)] (Sofia: Bǔlgarski Khudozhnik, 1980), 9-14.

30) Guglielmo Cavallo et al., I Bizantini in Itaria [The Byzantines in Italy (in Italian)], (M ilan: Libri Scheiwiller, 1982), 244.

31) 11 世紀創建の Type-C の遺構である Chalki H. Geōrgios (64) およびRossano (81) がいずれも推定創建年代が 11 世紀後半であるのに対し、11 世紀創建の Type-B の遺構である Stilo (82)、Vatopedi chapel (21) およびH. A postoloi (38) がいずれも 11 世紀前半である点から (Stilo (82): 975-1025、Vatopedi chaoel (21): 1001-1025、H. A postoloi (38): circa 1018)、Type-B は Type-C に先行し

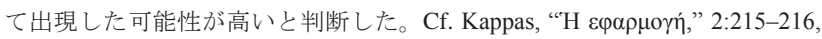

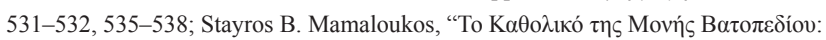

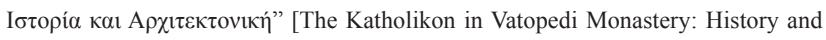
A rchitecture (in Greek)] (PhD diss., National Technical University of A thens, 2001) 207; A lison Frantz, The Church of the Holy Apostles (Princeton: A merican School of Classical Studies at A thens, 1971), 24-26.

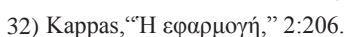

33) Ousterhout, Master Builders, 30 


\title{
THE DEVELOPMENT OF THE CROSS-IN-SQUARE CHURCH IN THE MIDDLE BYZANTINE PERIOD IN TERMS OF ITS ARCHITECTURAL CONFIGURATION
}

\author{
Ryo HIGUCHI* and Satoshi NASU**
}

* Doctoral Course, Tokyo Institute of Technology, M. Eng.
${ }^{* *}$ Assoc. Prof., Tokyo Institute of Technology, Dr. Eng.

The gap between early (4th-7th centuries CE) and middle (9th-12th centuries CE) Byzantine architecture makes it difficult to understand the development from the early period, which can be regarded as late Roman architecture, or architecture derivative of Roman examples, to middle Byzantine architecture, which acquires characteristics quite different from Roman architecture. In other words, scholars do not know where the specific characteristics of Byzantine architecture come from, which appear after the gap. The socalled 'cross-in-square' churches are clearly different from earlier buildings, because of their three-dimensional characteristics. These cases may provide significant clues for answering these questions, because it was one of the most common and favoured church forms during the middle Byzantine empire. However, the origin and early development of the cross-in-square form was unknown, because few buildings remain from this period; also, the three-dimensional characteristics of the cross-in-square form have often been overlooked in previous studies, which have focussed on certain areas or specific sites, rather than throughout the Byzantine territories. This paper examines how the architectural configuration, a combination of three-dimensional shapes and construction methods inside the cross-insquare churches, developed, with a particular focus on the crossed bays and corner bays that connect these two interior spaces.

First, this study defines the cross-in-square form, because previous studies have only roughly agreed what is under discussion, without clearly defining this key term. We examined the figural characteristics of cross-in-square churches of precious studies(Table 1) and how they yield various sub-types (Fig. 3). Based on these studies, the 'cross-in-square' church includes many possible forms: a single-story church with nine bays and a dome on four supports; four vaulted cross arms expanding in the main axes; and four corner bays in the diagonal axes (Fig. 4). From this definition, we sampled 154 churches; this paper addresses 84 of those cases (Fig. 5; Table 2) for which three-dimensional information is available.

Then, we categorised the churches into 14 types according to the arrangement of the arches and the number of the highest arches (Fig. 6), according to the patterns of the horizontal section of supports (Fig. 7) and according to the positional relationship between the bema and the dome bay (Fig. 8). These types are further classified into two groups based on similarities of each type, especially such interior architectural characteristics such as the construction methods used for supports and arches and the pattern of connection for arches and supports (Table 3). One type has arches of the same height, and supports and arches are discrete as those were made by different construction methods or clearly divided by shapes of supports and arches; the other features north-south arches that are higher than the east-west arches, while eastern supports divide the naos from the bema. As both groups feature a main dome which may be of average size (diameter ca. 3-5 metres), smaller (less than 3 metres) or larger (more than 5 metres), the difference between the two types is not correlated with the size of the main dome (Table 4).

From the perspective of its overall configuration, the former group (Type-A-D in Table 3) of churches is similar to one centralised structure, as all arches on the supports are the same height. We considered this group in terms of the types of arches placed on the supports. In the second group (Type-F-Direct-G in Table 3), the arches are two-directional, with arches and supports built integrally. Then we consider second group featuring walls in an east-west direction, penetrated by arches. From this examination, we conclude that cross-in-square churches developed in more than two ways, based on their interior architectural characteristics, in spite of the overall similarity in their floor-plans. 